Recebido em 09/05/01

Aceito para publicação em 19/06/01

\title{
Difteria: profissionais susceptíveis, diagnóstico, vacinação e reparação de danos
}

\author{
Diphtheria: Unproctected professionals diagnosis, vaccination and patients idemnity
}

Desde 1968 estamos estudando o Corynebacterium diphtheriae e a difteria $(1,9)$, mas só recentemente tivemos um caso clínico afetivamente muito próximo. A paciente (advogada) era vacinada, e o diagnóstico de laboratório foi fundamental. Somente após a identificação bacteriana, o tratamento específico foi iniciado, com boa resposta clínica (Mattos-Guaraldi, A.L. et al. Diphtheria in a vaccinated adult in Rio de Janeiro, Brazil. Brazilian Journal of Microbiology, in press, 2001).

Em difteria também devemos tudo fazer para rápido chegar ao diagnóstico de certeza, mesmo sabendo que "a clínica é soberana" $(1-4,7)$.

Este caso nos fez, mais uma vez, lembrar aquele antigo professor que se recusava a discutir "o melhor ataque da seleção brasileira" após sair da sala de aula. Ele dizia que "o médico interfere no campo do sujeito, no seu corpo e, por vias indiretas não apenas contingentes, em sua vida pessoal, nas suas emoções, na sua economia. Por isso é a medicina uma profissão moral". No laboratório de bacteriologia clínica não pode ser diferente. O microbiologista não trabalha apenas com o micróbio. Há sempre um paciente, um aluno, enfim uma pessoa por trás deste exame ou desta aula - mesmo na universidade, a responsabilidade do docente pesquisador não está apenas na pesquisa de ponta $(5,6)$.

A Lei de Defesa do Consumidor vem sendo invocada para dar suporte às pretensões de indenização de pacientes que buscam socorro nas barras dos tribunais. Destacamos o seguinte: "O fornecedor de serviços responde, independentemente da existência de culpa, pela reparação dos danos causados aos consumidores por defeitos relativos à prestação de serviços". Daquele diploma legal, os advogados vêm salientando este início do artigo 14.

O tratamento inicial da paciente (advogada) foi inadequado porque falhamos no diagnóstico clínico.

Após ampla vacinação e erradicação dos países desenvolvidos, a difteria praticamente desapareceu das cogitações da maioria dos pesquisadores no mundo. Apesar de bem estudada, anotam-se recentes observações, como a descrição de uma transialidase no $C$. diphtheriae, enzima importante na interação bactéria- hospedeiro, ou, até mesmo, a inesperada invasividade encontrada em um patógeno de baixo poder invasor (8). É doença onde a vacinação é prática eficaz! Com a cobertura vacinal cai vertiginosamente o número de casos. No entanto é virtual o desaparecimento do bacilo, que passa a ser encontrado como atoxinogênico e confundido com os "difteróides" (3).

Atualmente, o número de notificações está longe das cifras encontradas na década de 70. De 1980 a 1990, o microrganismo ocasionou surtos esporádicos em poucas regiões do território nacional $(4,5)$.

$\mathrm{O}$ bacilo diftérico tem sido encontrado em sítios incomuns, como ouvidos, conjuntiva e vagina. A colonização de pacientes adultos desperta grande interesse. Entre nós, o bacilo já foi isolado de espermocultura e de úlceras leishmanióticas $(3,4)$.

Embora continue apresentando sensibilidade à maioria dos antimicrobianos $(1,9)$, o microrganismo foi encontrado, em um caso de endocardite mitral fatal, resistente à penicilinoterapia, no Rio de Janeiro (8). $\mathrm{O}$ microrganismo isolado do paciente demonstrou produção de exotoxina no teste de imunodifusão radial simples. No entanto não foram encontrados sinais visiveis de toxemia. Hoje já se advoga que alguns clones apresentam propriedades invasoras.

O número de casos notificados é pequeno em comparação com o encontrado em décadas anteriores. Entretanto o seu isolamento nos deixa repletos de expectativas, quando o material clínico utilizado é proveniente de instituições onde predominam pacientes com baixa resistência imunológica (4).

No laboratório do Instituto Nacional do Câncer, no Rio de Janeiro, foi isolada recentemente uma amostra toxinogênica de $C$. diphtheriae, variedade mitis, fermentadora de sacarose, de uma lesão ulcerada de carcinoma infiltrado basalóide, de um paciente de 45 anos de idade, no período pré-operatório (MattosGuaraldi, A.L. et al. Corynebacterium diphtheriae threats in cancer patients. Revista Argentina de Microbiología, 33(2): 2001).

Casos como os acima referidos permitem-nos reafirmar a necessidade de cuidadosa identificação das 
amostras de bastonetes gram-positivos isoladas nos laboratórios de microbiologia clínica. Esta é uma conduta importante, particularmente porque outros microrganismos "corineformes", resistentes a antimicrobianos, são identificados como agentes etiológicos em diversos quadros clínicos (7).

Fé e razão precisam caminhar juntas. Ao acreditar que uma doença como a difteria desapareceu de nosso ambiente estamos correndo o grave risco de não diagnosticá-la, não só clinicamente, a tempo de poder bloquear a ação da poderosa exotoxina.

No laboratório do hospital, diante de uma espermocultura, de uma hemocultura ou, ainda, de uma lesão de carcinoma onde foram encontrados associados cocos piogênicos, coagulase-positivos, poderíamos ter rotulado o $\mathrm{C}$. diphtheriae, bastonete grampositivo, como difteróide (4).

Estudos sobre a superfície bacteriana, suas adesinas e, ainda, a determinação da existência de uma enzima, como a transialidase, capaz de contribuir para a etiopatogenia da doença são informações de relevância (8). No entanto, diante da realidade brasileira e sob o ponto de vista da saúde pública, o diagnóstico clínico precoce, o diagnóstico bacteriológico adequado e a vacinação "ampla, geral e irrestrita" de toda a população susceptível, adulta ou não, profissional de saúde ou não, continuam sendo os nossos maiores desafios.

Após três décadas de controle absoluto, a difteria ressurgiu em países europeus de maneira epidêmica. O ocorrido na Federação Russa, com mais de 100 mil casos relatados no período de 1990 a 1994, transformou-se no maior surto recente da doença (8). A situação atual da população brasileira guarda semelhança com as condições dos locais da Europa onde o bacilo diftérico causou problemas não apenas em crianças. Estudos realizados no exterior demonstraram que $50 \%$ dos adultos apresentavam níveis baixos de anticorpos protetores antitóxicos. Por esse motivo recomendaram-se, de modo geral, a revacinação de adultos e, em particular, a imunização dos profissionais de saúde. O risco de exposição, na área de saúde, a este agente patogênico por excelência, em particular nos laboratórios de bacteriologia, tem nos deixado apreensivos. Em alguns casos, de forma displicente, estamos descartando os bastonetes gram-positivos após rotulálos como inofensivos difteróides.

Como andará a imunidade de nossos médicos, enfermeiros, auxiliares de enfermagem e estudantes de biomedicina, farmácia, enfermagem e medicina? Será que já somos capazes de fabricar e oferecer esta vacina para todos? Mais da metade de nossos infectologistas, pediatras e bacteriologistas talvez nem tenha renovado a vacinação nos últimos dez anos.

Quando foi a sua última dose?

Luiz Carlos D. Formiga Instituto de Microbiologia Professor Paulo de Cóes, Universidade Federal do Rio de Janeiro

Ana Luiza Mattos Guarald Faculdade de Ciências Médicas da Universidade do Estado do Rio de Janeiro

\section{Referências}

1. Formiga, L.C.D. et al. Estudo in vitro sobre a sensibilidade do Corynebacterium diphtheriae a treze antibióticos. Rev. Microbiol., 2: 117-27, 1971.

2. Formiga, L.C.D. Studies on the genus Corynebacterium: contribution to the bacteriology of erythrasma and diphtheria. Brazilian J. Med. Biol. Res., 13: 88-9, 1980.

3. Formiga, L.C.D. New possibilities for laboratory diagnosis of diphtheria. Brazilian J. Med. Biol. Res., 18: 401-2, 1985.

4. Formiga, L.C.D. \& Mattos-Guaraldi, A.L. Diphtheria: current status and laboratory procedures for diagnosis. Rev. Bras. Pat. Clin., 29: 93-6, 1993.

5. Formiga, L.B.; Formiga, L.C.D. \& Gomes, R.O. Difteria: iatrogenia da omissão. Pediatria Atual, 7: 27-31, 1994.
6. Formiga, L.C.D. Ensino, pesquisa e ética na microbiologia médica. Sociedade Brasileira de Microbiologia - Notícias, 21: 3-4, 1998

7. Formiga, L.C.D. Corynebacterium. In: Trabulsi, L.R. et al. (eds.) Microbiologia. São Paulo: Atheneu, 1999. p. 177-85.

8. Mattos-Guaraldi, A.L.; Formiga, L.C.D. \& Pereira, G.A. Cell surface components and adhesion in Corynebacterium diphtheriae. Microbes and Infection, 2: 1-6, 2000.

9. Silva, A.C.P. et al. La acción de la gentamicina sobre bacilos diftéricos. Symposium Latinoamericano sobre Infecciones y Gentamicina. México, D.F.: Estela S.A., 1969. p. $171-4$ 